\title{
COVID-19 During Pregnancy: The Role of the Mother and Baby in Every Decision
}

\author{
Hamilelikte COVID-19: Her Kararda Anne ve Bebeğin Rolü
}

Nazlı Çetin', Erhan Uğurlu', Merve Türkarslan', Cihan Kabukçu², Furkan Ufuk ${ }^{3}$

Abstract

Contracting COVID-19 during pregnancy is a clinical concern as knowledge of altered immunity is limited, and so cases should be considered separately in terms of diagnosis and treatment. Although there is no clear evidence that pregnancy increases the risk of COVID-19, it is thought that susceptibility to infection and the intensification of respiratory symptoms may be increased, given the physiological changes in pregnancy and increased mortality and morbidity in many viral diseases. Accordingly, the management of COVID-19 in pregnant patients and those considered among the high-risk groups represent a challenge for clinicians. Numerous studies of COVID-19 have been published to date or are ongoing, yet pregnant women are generally excluded from clinical studies. Clinical experiences and case reports occupy an important position in literature, and we present hare a case in which the diagnosis of a patient being followed by our clinic was delayed due to the absence of SARS CoV-2 in recurrent upper-respiratory-tract sampling, and whose clinical findings worsened with initial COVID-19 treatment during pregnancy. Her delivery by caesarean section (C-section) was the result of a multidisciplinary decision. We draw attention to the diagnostic process and treatment approach.

Key words: Coronavirus, COVID-19, pregnancy, delivery, caesarean section.

\section{Özet}

Gebelikte COVID-19, değişen immunite; tanı ve tedavideki farklılıklar ile ayrı ele alınması gereken, bilgilerimizin sınırlı olduğu bir klinik tablodur. Gebelikte gerçekleşen fizyolojik değişiklikler ve pek çok viral hastalıkta artmış mortalite ve morbidite göz önüne alındığında, gebeliğin enfeksiyonlara yatkınlığa ve solunumsal semptomlarda şiddetlenmeye neden olabileceği düşünülmektedir. Bu nedenle riskli gruplar arasında değerlendirilmesi gereken gebelerde COVID-19 yönetimi klinisyenler için zorluklar içermektedir. COVID-19 ile ilgili çok sayıda çalışma yayınlanmış ya da devam etmekte olsa da gebeler genellikle klinik çalışmaların dışında tutulmaktadır. Bu nedenle klinik deneyimler, olgu paylaşımları literatürde önemli bir yer tutmaktadır. Kliniğimizde takip ettiğimiz, tekrarlayan üst solunum yolu örneklemelerinde SARS CoV-2 saptanmaması nedeniyle tanısı geciken, gebelikte kullanılabilen COVID-19 tedavisi alıında klinik bulgularda kötüleşme olması üzerine multidisipliner yaklaşım ile sezaryen kararı alınarak tedavisi şekillendirilen olgumuzu, tanı süreci ve tedavi yaklaşımına dikkat çekerek sunmayı amaçladık.

Anahtar Sözcükler: Koronavirüs, COVID-19, gebelik, doğum, sezaryen.
'Department of Chest Diseases, Faculty of Medicine, Pamukkale University, Denizli, Turkey

${ }^{2}$ Department of Gynecology and Obstetrics, Faculty of Medicine,

Pamukkale University, Denizli, Turkey

${ }^{3}$ Department of Radiology, Faculty of Medicine, Pamukkale University, Denizli, Turkey

\author{
'Pamukkale Üniversitesi Tıp Fakültesi, Göğüs Hastalıkları \\ Anabilim Dalı, Denizli \\ 2Pamukkale Üniversitesi Tıp Fakültesi, Kadın Hastalıkları ve \\ Doğum Anabilim Dalı, Denizli \\ ${ }^{3}$ Pamukkale Üniversitesi Tıp Fakültesi, Radyoloji Anabilim \\ Dalı, Denizli
}

Submitted (Başvuru tarihi): 01.02.2021 Accepted (Kabul tarihi): 01.04 .2021

Correspondence (iletişim): Nazlı Çetin, Department of Chest Diseases, Faculty of Medicine, Pamukkale University, Denizli, Turkey

e-mail: nazlicetin@yandex.com 
The novel 2019 coronavirus disease (COVID-19) has radically altered clinical practice all around the world over the past year. More than 90 million people had been infected globally as of January 14, 2021 (1). COVID-19 during pregnancy is a clinical concern due to the limited knowledge of altered immunity; thus, cases should be considered separately in terms of diagnosis and treatment. A search of literature produced digitized patient data from recent reviews (2-4).

Although there is no clear evidence that pregnancy increases the risk of COVID-19, it is thought that susceptibility to infection and intensification of respiratory symptoms may be increased, given the physiological changes in pregnancy and increased mortality and morbidity in many viral diseases $(2,5)$. Accordingly, COVID-19 management in pregnancy, and who should be considered among the high-risk groups, presents challenges to clinicians. We present here the case of a pregnant patient being followed by our clinic whose treatment was shaped by a multidisciplinary approach, leading to the decision to perform a $\mathrm{C}$-section due to the deterioration of clinical findings under treatment, drawing attention to the diagnostic process and treatment approach.

\section{CASE}

A 30-year-old patient who was 38 weeks pregnant presented with a complaint of fatigue for the last week, a fever of $39^{\circ} \mathrm{C}$ for 3 days, and a cough. Upon examination, the patient was also found to have rhinorrhea, impaired taste and smell, muscle pain (especially in the legs), lack of appetite and dysuria. The patient had visited different centers with these complaints, during which a reverse transcriptase polymerase chain reaction (RT-PCR) was negative for Severe Acute Respiratory Syndrome Coronavirus 2 (SARS CoV-2) taken from nasooropharyngeal swab samples on four different days. The simultaneous SARS CoV-2 rapid antibody test was also negative. Although empirical antibiotherapy was started immediately, the patient's complaints increased. When the patient's history was questioned, it was learned that she had not had a common disease before, had two healthy births by the vaginal route, and had never smoked. Her family history was insignificant. A physical examination revealed an averaged pulse; $\mathrm{O}_{2}, 94 \%$ in room air; fever, $38.6^{\circ} \mathrm{C}$; and normal respiratory sounds on auscultation.
The results of a laboratory examination were leukocyte, $7.44 \mathrm{~K} / \mathrm{uL}$; lymphocyte, $0.71 \mathrm{~K} / \mathrm{uL}$; neutrophil-tolymphocyte ratio (NLR), 9.1; C-reactive protein (CRP), $83.69 \mathrm{mg} / \mathrm{L}$; ferritin, $89.7 \mu \mathrm{g} / \mathrm{L}$; procalcitonin, 0.41 $\mathrm{ng} / \mathrm{mL}$; d-dimer, $861 \mathrm{ng} / \mathrm{mL}$; and fibrinogen, $647 \mathrm{mg} / \mathrm{Dl}$. Although the clinical and laboratory findings suggested a SARS CoV-2 infection pre-diagnosis, due to the hesitation of the patient and her relatives based on the negative repeated PCR tests, consent was obtained to carry out postero-anterior chest radiography (Figure 1), followed by chest computed tomography (CT) (Figure 2) imaging. The chest $\mathrm{CT}$ images were obtained using a low-dose protocol as follows: $120 \mathrm{kVp}, 30 \mathrm{mAs}, 2 \mathrm{~mm}$ slice thickness, and $1 \mathrm{~mm}$ slice reconstruction. The imaging findings were compatible with COVID-19, and the patient was admitted to the pandemic service as a possible case. In the followup, the RT-PCR of mucus was positive.

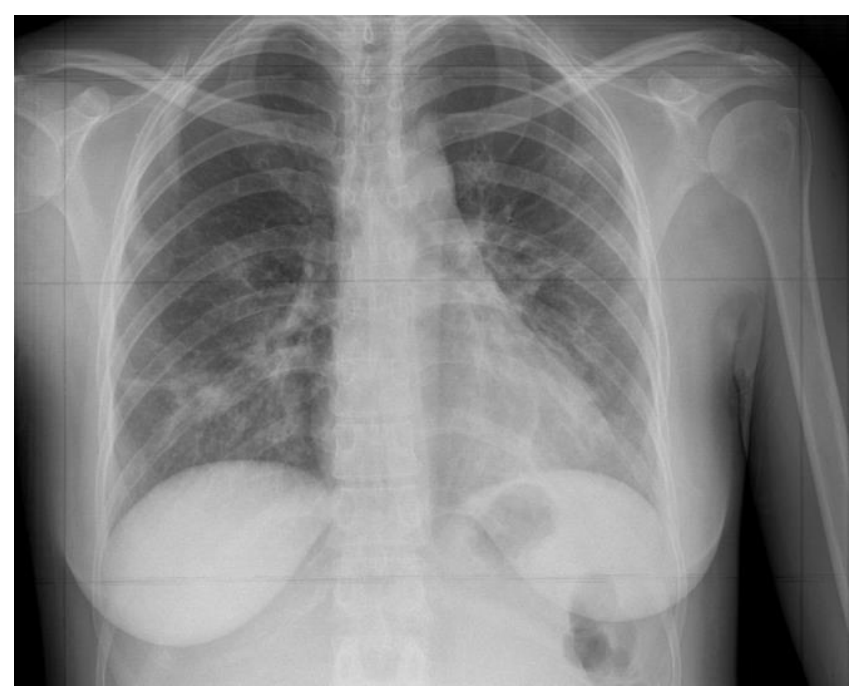

Figure 1: Postero-anterior chest radiography at hospitalization

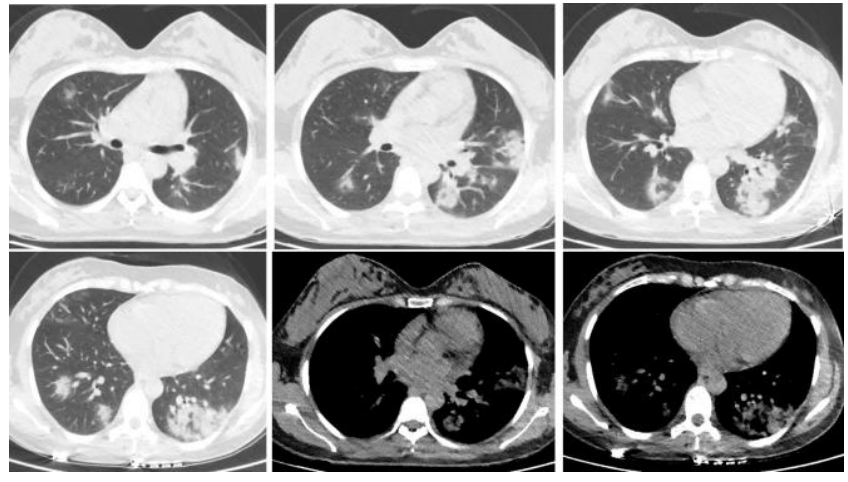

Figure 2: Thorax computed tomography (CT) at hospitalization 
Table 1: Laboratory parameters

\begin{tabular}{|c|c|c|c|c|}
\hline & $\begin{array}{c}\text { Hospitaliza- } \\
\text { tion }\end{array}$ & First day & Second day & Discharge \\
\hline Leukocyte (k/ul) & 7,44 & 9,57 & 10,43 & 8,8 \\
\hline Neutrophil (k/ul) & 6,47 & 8,45 & 9,05 & 6,45 \\
\hline Lymphocyte (k/ul) & 0,71 & 0,79 & 1,04 & 1,84 \\
\hline NLR & 9,11 & 10,1 & 10,7 & 3,51 \\
\hline CRP (mg/l) & 83,69 & 120 & 144 & 11,16 \\
\hline Ferritin (ug/l) & 89,7 & 171 & 159 & 129 \\
\hline D-dimer (ng/ml) & 861 & 1189 & 411 & 471 \\
\hline Fibrinoien (mg/dl) & 629 & 647 & 647 & 426 \\
\hline
\end{tabular}

${ }^{*}$ NLR: neutrophil-to-lymphocyte ratio, CRP: C - reactive protein

Obstetric evaluation, ultrasonography and non-stress test (NST) findings were normal, and fetal measurements were consistent with the gestational week. No emergency obstetric intervention was considered, and follow-up with NST was recommended.

Lopinavir/ritonavir 200/50mg PO 2x2, ertapenem 1 gr IV $1 x 1$ and enoxaparin 6000 IU SC 2x1 were initiated. The patient's fever was $39.6^{\circ} \mathrm{C}$ with respiratory disorder, and she developed hemoptysis with coughing; saturation was $92 \%$ with $2 \mathrm{l} / \mathrm{min}$ nasal $\mathrm{O}_{2}$ on day 2 of hospitalization. A laboratory examination revealed leukocyte, $10.43 \mathrm{~K} / \mathrm{uL}$; lymphocyte, $0.79 \mathrm{~K} / \mathrm{uL}$; NLR, 12.3; CRP, $144 \mathrm{mg} / \mathrm{L}$; ferritin, $171 \mu \mathrm{g} / \mathrm{L}$; and D-dimer, $1189 \mathrm{ng} / \mathrm{mL}$. An obstetrical evaluation of the patient was performed with and the disease symptoms process was repeated, and based on a decision of the multidisciplinary council, an emergency $C$ section was planned with spinal anesthesia rather than cervical maturation and labor induction. The C-section was indicated due to fetal tachycardia, which was attributed to the high maternal body temperature, and which suggested a non-reassuring fetal status. After the C-section, the patient's treatment was revised to favipiravir PO 2x1600 mg after loading, 2×300 mg, methylprednisolone IV $40 \mathrm{mg}$ 1x1 (dose reduced according to clinical monitoring), antitussive agents and enoxaparin. The patient's pulse $\mathrm{O}_{2}$ at room air was 94\%, her laboratory parameters returned to normal (Table 1), her symptoms regressed, and along with the infiltration on postero-anterior chest radiography (Figure 3), and she was discharged on day 9 following admission. A RT-PCR was negative in two samples taken from the newborn on different days, and no clinical pathology was observed at follow-up or any COVID-19 finding. A newborn examination was normal.

\section{DISCUSSION}

Although the accepted diagnostic method in COVID-19 involves the detection of SARS CoV-2 by RT-PCR, its sensitivity has been reported to be in the $30-60 \%$ range $(6,7)$. The accuracy of the RT-PCR test can be affected by many factors, such as respiratory viral load, sample source, sampling procedures and timing, the quality control of the test and the performance of test kits (8). Studies support the finding that RT-PCR positivity may be detected more frequently in lower-respiratory-tract samples (9). In our case, nasopharyngeal and oropharyngeal samples were taken on consecutive days - all were negative, while RT-PCR positivity was detected in the mucus sample. In addition delaying diagnosis, this situation affects the compliance of the patient with treatment and isolation. In cases where lower-respiratory-tract sampling cannot be performed, or if it is performed, it takes time to obtain the results, or if the results are negative, even though clinical and laboratory findings support COVID-19, it is recommended that possible cases be identified to avoid delaying treatment and the application of isolation measures (10). Fever, cough, shortness of breath and lymphopenia are common findings in pregnant women, and these are similar to the findings in the normal population (2).

Pulmonary imaging is another important diagnostic tool due to its rapid results and its ability to produce findings in cases where RT-PCR is negative (7). Although the risks 
to the fetus due to radiation exposure are known, radiological imaging should be performed when necessary, with the appropriate dosage and with the use of protective measures (11). According to data from the American College of Radiology and American College of Obstetricians and Gynecologists, the fetal radiation dose is 0.01 $0.66 \mathrm{mGy}$ from a single thorax CT, which is lower than the dose associated with fetal harm (12). Although the repeated RT-PCR tests were also negative in our case, the presence of findings compatible with COVID-19 in thoracic $\mathrm{CT}$ were identified diagnostically. It has been reported that consolidation occurs more frequently in pregnant women (13). Consolidation-weighted infiltrates were also observed in our case. (Figure 2)

There are several discussions and ongoing clinical trials related to COVID-19 treatment. There is as yet no clear evidence of treatment with proven efficacy and safety in pregnant women (14). Hydroxychloroquine and lopinavir/ritonavir are recommended due to being safe (15), although the FDA withdrew its approval for its use in COVID-19 due to the lack of efficacy of hydroxychloroquine, and the reported cardiac side effects (16). The antiviral favipiravir and remdesivir treatments have been reported to be effective in treatment, and while the teratogenicity of favipiravir is known, that of remdesivir has not yet been studied (14). In our case, lopinavir/ritonavir treatment was initiated in accordance with the guidelines. The addition of antibiotics to the treatment regimen for COVID-19 is controversial, but in our case, ertapenem was initiated due to the dysuria and leukocyturia identified in a complete urinalysis, and the patient's history of antibiotic use. Corticosteroids are recommended in cases of severe illness and the need for oxygen in the treatment of COVID-19 $(17,18)$. The teratogenicity of corticosteroids during pregnancy has not been demonstrated, but fetal malformations associated with high doses have been reported in animal studies (19). In our case, no prenatal

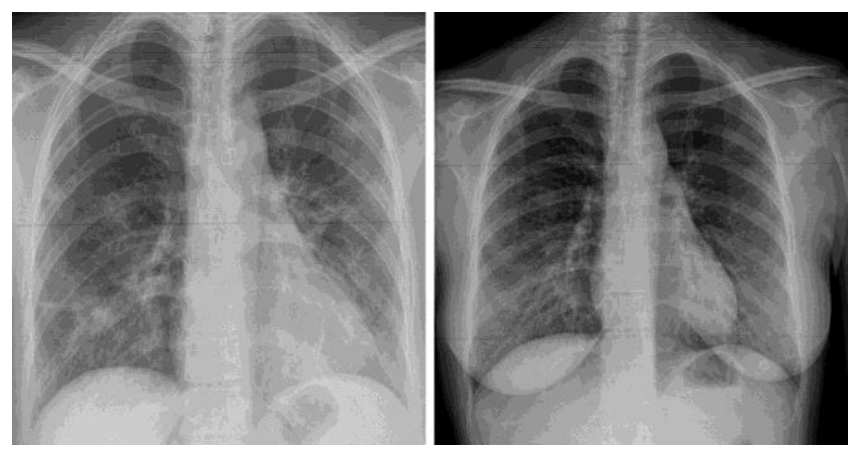

Figure 3: Comparison of postero-anterior chest radiography at hospitalization and discharge corticosteroids were used due to the C-section decision and the appropriate development of the fetus. Postnatally, $40 \mathrm{mg} /$ day methylprednisolone was initiated and the dose was reduced based on the results of the clinical follow-up, with the patient being discharged on 16 $\mathrm{mg} /$ day $\mathrm{PO}$ methylprednisolone.

An important decision in the management of pregnant COVID-19 patients is the timing and mode of delivery. $\mathrm{C}$-sections are performed based on the indication of maternal respiratory distress in most reported cases (20). It is known that physiological changes occurring during pregnancy may lead to decreased cardiac and pulmonary reserves. The diaphragm attachment to the uterus increases and functional residual capacity decreases, especially in the third trimester (21). This may lead to rapid oxygenation deterioration, especially in pregnant women with COVID-19 pneumonia. In order to provide oxygenation from the placenta to the fetus during pregnancy, oxygen saturation should be maintained at $95 \%$ or above (14). However, birth itself is a source of stress and may increase the risk of infection and thromboembolic events, while also exacerbating the irregular inflammatory response in those with underlying infections (21). Continued fever, deterioration of oxygenation, and changes in laboratory parameters despite the treatment, initiated in accordance with the safety profile during pregnancy, indicated the potential of the disease to worsen in our patient's case. Considering the fetal situation, despite risks such as the development of the need for intensive care, lower cardiopulmonary reserve and potential emergency surgery, the decision to perform a C-section was made after a joint evaluation by a pulmonologist and a gynecologist.

\section{CONCLUSION}

The management of COVID-19 in pregnancy is complex for many reasons, including physiological changes related to pregnancy, the maintenance of fetal well-being, and diagnosis and treatment limitations, and there may be a number of psychosocial considerations, such as the patient's anxiety and that of her family. Although there have been many studies of COVID-19 and many that are ongoing, pregnant women are generally excluded from clinical studies. Clinical experiences and case reports play 
an important role in literature. In the presence of clinical findings compatible with COVID-19 despite RT-PCR tests being negative, we recommend radiological imaging and microbiological tests be carried out on different samples, especially form the lower-respiratory tract, and studied with appropriate methods.

\section{CONFLICTS OF INTEREST}

None declared.

\section{AUTHOR CONTRIBUTIONS}

Concept - N.Ç., E.U., M.T., C.K., F.U.; Planning and Design - N.Ç., E.U., M.T., C.K., F.U.; Supervision - N.Ç., E.U., M.T., C.K., F.U.; Funding - N.Ç., E.U., M.T.; Materials -; Data Collection and/or Processing - N.Ç., M.T.; Analysis and/or Interpretation - N.Ç., E.U., C.K., F.U.; Literature Review - N.Ç.; Writing - N.Ç., E.U., M.T., C.K., F.U.; Critical Review - E.U., C.K., F.U.

\section{YAZAR KATKILARI}

Fikir - N.Ç., E.U., M.T., C.K., F.U.; Tasarım ve Dizayn N.Ç., E.U., M.T., C.K., F.U.; Denetleme - N.Ç., E.U., M.T., C.K., F.U.; Kaynaklar - N.Ç., E.U., M.T.; Malzemeler -; Veri Toplama ve/veya İşleme - N.Ç., M.T.; Analiz ve/veya Yorum - N.Ç., E.U., C.K., F.U.; Literatür Taraması - N.Ç.; Yazıyı Yazan - N.Ç., E.U., M.T., C.K., F.U.; Eleştirel İnceleme - E.U., C.K., F.U.

\section{REFERENCES}

1. WHO. Accessed date: 2021 Jan 13. Available from: https://www.who.int/emergencies/diseases/novelcoronavirus-2019.

2. Dashraath $P$, Wong JLJ, Lim MXK, Lim LM, Li S, Biswas $A$, et al. Coronavirus disease 2019 (COVID-19) pandemic and pregnancy. Am J Obstet Gynecol 2020; 222:521 31. [CrossRef]

3. Pettirosso E, Giles M, Cole S, Rees M. COVID-19 and pregnancy: A review of clinical characteristics, obstetric outcomes and vertical transmission. Aust N Z J Obstet Gynaecol 2020; 60:640-59. [CrossRef]

4. Chen H, Guo J, Wang C, Luo F, Yu X, Zhang W, et al. Clinical characteristics and intrauterine vertical transmission potential of COVID-19 infection in nine pregnant women: a retrospective review of medical records. Lancet 2020; 395:809-15. [CrossRef]

5. Mor G, Cardenas I, Abrahams V, Guller S. Inflammation and pregnancy: the role of the immune system at the implantation site. Ann N Y Acad Sci 2011; 1221:80-7. [CrossRef]
6. Yang $Y$, Yang M, Yuan J, Wang F, Wang Z, Li J, et al. Comparative sensitivity of different respiratory specimen types for molecular diagnosis and monitoring of SARSCoV-2 shedding. Innovation (N Y) 2020; 1:100061. [CrossRef]

7. Ai T, Yang Z, Hou H, Zhan C, Chen C, Lv W, et al. Correlation of chest $C T$ and RT-PCR testing for coronavirus disease 2019 (COVID-19) in China: a report of 1014 cases. Radiology 2020; 296:E32-E40. [CrossRef]

8. Chan JF, Yip CC, To KK, Tang TH, Wong SC, Leung KH, et al. Improved molecular diagnosis of COVID-19 by the novel, highly sensitive and specific COVID-19-RdRp/Hel real-time reverse transcription-PCR assay validated in vitro and with clinical specimens. J Clin Microbiol 2020; 58:e00310-20. [CrossRef]

9. Pan Y, Zhang D, Yang P, Poon LLM, Wang Q. Viral load of SARS-CoV-2 in clinical samples. Lancet Infect Dis 2020; 20:411-2. [CrossRef]

10. WHO COVID-19: Case Definitions. Accessed date: 2021 Jan 13. Available from: https://www.who.int/publications/i/item/WHO-2019nCoV-Surveillance Case Definition-2020.1.

11. Tomà $P$, Bartoloni $A$, Salerno $S$, Granata $C$, Cannatà V, Magistrelli $A$, et al. Protecting sensitive patient groups from imaging using ionizing radiation: effects during pregnancy, in fetal life and childhood. Radiol Med 2019; 124:736-44. [CrossRef]

12. Committee Opinion No. 723: Guidelines for diagnostic imaging during pregnancy and lactation. Obstet Gynecol 2017; 130: e210-e216. Accessed date: 2021 Jan 13. Available from: https://www.acog.org/clinical/clinicalguidance/committeeopinion/articles/2017/10/guidelines-for-diagnosticimaging-during-pregnancy-and-lactation. [CrossRef]

13. Liu H, Liu F, Li J, Zhang T, Wang D, Lan W. Clinical and CT imaging features of the COVID-19 pneumonia: Focus on pregnant women and children. J Infect 2020; 80:e7-e13. [CrossRef]

14. Marim F, Karadogan D, Eyuboglu TS, Emiralioglu N, Gurkan CG, Toreyin ZN, et al. Lessons learned so far from the pandemic: a review on pregnants and neonates with COVID-19. Eurasian J Med 2020; 52:202-10. [CrossRef]

15. TC. Sağlık Bakanlığı Halk Sağlığı Genel Müdürlüğü COVID-19 (Sars-CoV-2) enfeksiyonu rehberi. Accessed date: 2021 Jan $12 . \quad$ Available from: https://covid 19bilgi.saglik.gov.tr/depo/rehberler/COVID -19 Rehberi.pdf?type $=$ file.

16. Commissioner O. Coronavirus (COVID-19) update: FDA revokes emergency use authorization for chloroquine and 
hydroxychloroquine.

July

2020,

https://www.fda.gov/newsevents/press-

announcements/coronavirus-covid-19-update-FDA-

revokes-emergency-use-authorizationchloroquine-and

17. WHO/2019-nCoV/Corticosteroids/2020.1. Accessed date: 2021 Jan 18. Available from: https://www.who.int/publications/i/item/WHO-2019nCoV-Corticosteroids-2020.1.

18. T.C. Sağlık Bakanlığı COVID-19 (SARS-CoV-2 Enfeksiyonu) Ağır pnomoni, ARDS, sepsis ve septik şok yonetimi. 7 Kasım 2020. Accessed date: 2021 Jan 18. Available from:

https://covid 19.saglik.gov.tr/Eklenti/39297/0/covid-

19rehberiagirpnomoniardssepsisveseptiksokyontemipdf.p df.
19. Park-Wyllie L, Mazzotta P, Pastuszak A, Moretti ME, Beique $L$, Hunnisett $L$, et al. Birth defects after maternal exposure to corticosteroids: prospective cohort study and meta-analysis of epidemiological studies. Teratology 2000; 62:385-92. [CrossRef]

20. Della Gatta AN, Rizzo R, Pilu G, Simonazzi G. Coronavirus disease 2019 during pregnancy: a systematic review of reported cases. Am J Obstet Gynecol 2020; 223:3641. [CrossRef]

21. Alsayyed F, Hastings V, Lederman S. Expectant management of a critically ill pregnant patient with COVID-19 with good maternal and neonatal outcomes. Case Rep Obstet Gynecol 2020; 2020:8891787. [CrossRef] 